\title{
COVID-19 and social wellbeing in Malaysia: A case study
}

\author{
Siew Siew Yong $^{1}$ (D) Joseph Kee-Ming Sia $^{2}$ (D) \\ Accepted: 2 September 2021 \\ (C) The Author(s), under exclusive licence to Springer Science+Business Media, LLC, part of Springer Nature 2021
}

\begin{abstract}
The world has witnessed the largest single disruption to social wellbeing since the first known case of coronavirus disease 2019 (COVID-19) was reported in China in December 2019. In Malaysia, the government implemented the Movement Control Order (MCO) on 18 March 2020 in response to the COVID-19 pandemic. Thus, this paper highlights how the Malaysian government responded to COVID-19 in comparison with some Asian countries; and what has and has not worked for the MCO imposed by the government. The paper adopts a review approach that is supported by findings from both grey and academic literature. The findings reveal that the COVID-19 pandemic has significant impacts on the society's wellbeing in Malaysia, the most severe of which are negative mental health and job unemployment. On the other hand, COVID-19 has sparked a surge of volunteering in society. This paper presumably and hopefully represents a frontier review with more empirical research to be conducted to investigate the extent of the social impact of COVID-19, the outcomes of which are a call for re-envisioning of social policies in Malaysia. To the best knowledge of the authors, little empirical research has been conducted to explore the social-wellbeing implications of COVID-19 in Malaysia. By reflecting on the various scenarios - both detrimental and beneficial in the context of the COVID-19 pandemic, the paper identifies potential avenues for relevant research in the social wellbeing realm.
\end{abstract}

Keywords COVID- $19 \cdot$ Mental health $\cdot$ PEST $\cdot$ Social wellbeing $\cdot$ Malaysia

\section{Introduction}

On 25 January 2020, Malaysia announced its first COVID-19 case as an infected Chinese national who travelled to Malaysia from Singapore (Profdten \& Ahmad, 2021). While going through the transformative constitutional phase, an exponential rise in cases occurred due to a mass Islamic missionary gathering in Sri Petaling on 27 February 2020, which was reported as the highest number of coronavirus cases in Southeast Asia on 15 March 2020 (Mat et al., 2020; Song \& Ling, 2020). Consequently, the Malaysian government imposed the Movement Control Order (MCO) for the common good from 18 March 2020; it was replaced by the Conditional MCO

Siew Siew Yong

yongsiewsiew@postgrad.curtin.edu.my

Joseph Kee-Ming Sia

joseph@curtin.edu.my

1 Faculty of Business, Curtin University Malaysia, CDT 250, Miri, Sarawak, Malaysia

2 Department of Management, Marketing and Digital Business, Faculty of Business, Curtin University Malaysia, CDT 250, Miri, Sarawak, Malaysia
(CMCO) on 4 May 2020, and that has been subsequently replaced by the Recovery MCO (RMCO) since 10 June 2020. During the initial stage of MCO, it was difficult for the Malaysians to adhere to the drastic restrictions such as prohibited public gatherings and social distancing requirements; Malaysians are a sociable lot and social gathering is part and parcel of their everyday life (Aziz et al., 2020). The infodemic of unconfirmed and unreliable news spreading in the social media amplified the irrational fears among the Malaysians, leading to panic buying of essentials before the MCO (Azlan et al., 2020; Kaur et al., 2020). Qiu et al. (2020) indicated that information about COVID-19 in the social media caused tension and anxieties among young adults and women. Malaysia's human resource minister pointed out that 99,696 Malaysians had lost their jobs since the implementation of the MCO (Surendran, 2021). Unemployment and uncertainty of the future resulting from the pandemic can take a serious toll on the people's psychological wellbeing. The purpose of this paper is threefold: firstly, provide insights into the unprecedented Malaysian experience in responding to the COVID-19 pandemic in comparison with two Asian countries (Singapore and Taiwan); secondly, explore the implications of COVID-19 on social wellbeing; thirdly, conduct Political, Economic, Social, Technological (PEST) analysis with recommendations, and propose pertinent research questions for future investigations. 
This paper is divided into five sections. Firstly, we present the respective actions taken by Singapore, Taiwan, and Malaysia to mitigate COVID-19; we compare and contrast the policies of the three countries. Secondly, we critically analyze the success-enabling and success-disabling factors in mitigating COVID-19 based on the numbers of cases reported from March 2020 till January 2021 by the government of Malaysia, with reference to policies, standard operating procedures (SOPs), and enforcement in Singapore and Taiwan. Thirdly, we explicate the implications of COVID-19 on social wellbeing. Fourthly, we develop a PEST analysis and put forward a few recommendations. Finally, we propose various research ideas that need to be further investigated by future researchers. The discussions covered in this paper are premised on data available until 30 April 2021, as the war against COVID-19 is an ongoing effort.

\section{Asian Countries' Responses Towards COVID-19}

Singapore registered the world's lowest COVID-19 death rate thus far (Geddies \& Aravindan, 2020). The total number of deaths related to COVID-19 for Singapore is 29 as of 30 January 2021 (Ministry of Health Singapore, 2021). What is the secret of Singapore in reporting the lowest COVID-19 death figure in the world? One of the significant actions is that the government started temperature screening for all the travelers arriving from Wuhan since 3 January 2020, even though there was no reported case in their region at that period of time. This is vital as Singapore took prevention measures through border controls as soon as the disease emerged in Wuhan, China. Singapore detected the first COVID-19 case on 23 January 2020, and the government immediately imposed three phases of actions to combat the spread of the virus (Yong, 2020). Under Phase 1, they carried out aggressive testing, contact tracing, border control measures, early screening, and suspected patient isolation (Wang et al., 2021). The city-state moved to Phase 2 or safe transition on 19 June 2020 with the government imposing rules of wearing face masks in public places, and this is one of the significant steps to lower the possibility of another wave of COVID-19 (Geddies \& Aravindan, 2020). Under Phase 3, the government put in place strict community-wide measures by closing all the nonessential businesses and schools, and prohibited mass gatherings (Wang et al., 2021). Another action is levying heavy fines on and meting out punishments to those who failed to follow the rules set by the government - fined up to US $\$ 10,000$ or jailed for 6 months. Given the lessons learnt from the Severe Acute Respiratory Syndrome (SARS) epidemic, the Singapore government devised a disease-outbreak response strategy with activation levels similar to those of the World Health Organization (WHO) Pandemic Alert Response
System. Through early prevention measurements, strict enforcement of law, and meticulous contact tracing, Singapore has successfully controlled the spread of COVID-19; the reported numbers of daily new cases averaged of between 1 and 2 digits in January 2021 (Tan, 2021a). For financial aid, the Singapore government has provided COVID-19 support grant to the unemployed or low-income households. Since the outbreak of COVID-19, they have introduced Stabilization and Support Package, Resilience Budget, Solidarity Budget, and Fortitude Budget worth $\mathrm{S} \$ 4$ billion, $\mathrm{S} \$ 48.4$ billion, $\mathrm{S} \$ 5.1$ billion, and S\$33 billion respectively (KPMG, 2020a). These unemployment-reducing budgets are allocated as incentives for job support and job growth.

Taiwan had the world's best virus-prevention record by far with only 553 confirmed cases among 23 million citizens as at 31 October 2020, while the cumulative confirmed cases worldwide had reached 46.14 million with 1.20 million deaths (Wang \& Ellis, 2020). According to the Taiwan Centers for Diesease Control (2021), the country registered 1-digit COVID-19 daily cases throughout January 2021. People living in Taiwan have a psychological trauma and are better prepared for COVID-19; they possess a high degree of awareness after they experienced the SARS outbreak in 2003 (Lei \& Klopack, 2020). In addition, after the SARS catastrophe, their government established the Central Epidemic Command Centre (CECC) to introduce and monitor prevention measures for handling future pandemics. To facilitate rapid communications, the government activated the CECC as a physical command center on 20 January 2020 , a day before the first COVID-19 case was reported in Taiwan (Cheng et al., 2020). They also implemented mandatory self-quarantine, early border controls, banning foreign visitors; and employed big-data analytics to trace high-risk persons based on their medical or traveling history. Instead of shutting down its economy for weeks to halt the infection, Taiwan used a different approach. After rapidly shutting its borders and prohibiting the export of surgical masks, the authorities utilized contact tracing, and mobile sim-tracking to locate and ensure people under quarantine were following the laws (Jian et al., 2020). Yang et al. (2020) highlighted that when the virus cases spiked in China, the Taiwanese government stocked up on personal protective equipment (PPE) five times the required amount. This is a vital preemptive effort as most countries faced a shortage of PPE for the frontline and healthcare workers during the pandemic. The CECC also sets the price for PPE, and each resident in Taiwan can purchase a limited quantity of PPE only. In a nutshell, by learning from the previous SARS experience in 2003, the Taiwanese government and society responded swiftly to the COVID-19 pandemic by taking uncompromising preventive and control measures as those mentioned above. The concerted efforts contributed to the decline in the infectious disease with no occurrence of a second wave as of 31 January 2021. Taiwan's COVID-19 relief measures fall into 
three categories: financial aid, job support, and tax reductions. The government allocated a total of US\$35 billion for the special relief packages (Kuo, 2021). For financial aid, the public banks extended the loan repayment deadlines and deferred the credit card payments; the authorities adjusted the rent for national properties and supported small and medium enterprises by providing funds for business operations (KPMG, 2020b). In terms of job support, the government provided training programs and unemployment benefits (KPMG, 2020b). The government also allowed deferral of tax payments, conversion of lump sums to instalments, and waiver of corporate income tax payment for businesses affected by the pandemic (KPMG, 2020b).

In Malaysia, the Ministry of Health $(\mathrm{MoH})$ played a crucial role in containing the spread of the virus. They conducted aggressive mass testing by tracing all the contacts of infected people and enforced health screening at all access points (Aziz et al., 2020; Shah et al., 2020). The findings by Gill et al. (2020) posit that the ability to trace high numbers of contacts in a timely manner could control the COVID-19 outbreak successfully. Likewise, both Singapore and Taiwan are doing the same by controlling the suspected patients' movements to avoid another wave of infection. Drive-through screening tests that can be done within $5 \mathrm{~min}$ are available at various locations, and the $\mathrm{MoH}$ installed thermal scanners in all entry points to the country (Ch'ng, 2020; Tay et al., 2020). These measures are also implemented in Singapore and many other Asian countries.

Besides, the MoH has identified hospitals that would admit COVID-19 patients and hospitals that would act as screening and health centers. The hospitals also introduced telephone or internet consultation for non-urgent cases and only accepted urgent walk-in cases (Tay et al., 2020). Several scholars emphasized telemedicine's importance and the potential for further development in Malaysia (Abdullah et al., 2020; Khor et al., 2020). To obtain quality surveillance data, the $\mathrm{MoH}$ used the eNotifikasi, a web-based infectious disease reporting system to model the spread of COVID-19 (Gill et al., 2020). The hospitals also introduced the Cloud Auto Detection Solution to enable early detection and diagnosis of infected patients (Chung, 2020). Taiwan has introduced a similar platform named TRACE since 2017 and utilized this platform for monitoring the development of COVID-19.

To reduce the financial impacts of the pandemic, the Malaysian government introduced several emergency economic aids such as the Prihatin Rakyat Economic Stimulus Package (PRIHATIN), the National Economic Recovery Package (PENJANA), and KITA PRIHATIN Package worth a total of RM315 billion; these supporting monetary schemes are designed to ease the people's financial burden and help the enterprises who are struggling to retain their employees (The Star, 2020). The above economic packages include wage subsidy program 2.0 to support businesses faced with drops in revenue to ensure that their employees are getting reasonable wages and to reduce layoff or termination during the pandemic period. Consequently, those incentives sustained more than 300,000 enterprises, contained the unemployment rate, and saved 2.4 million jobs as of 24 June 2020 (Mohtar, 2020). Comparatively, Malaysia allocated the highest fiscal policy package to ease the people's financial burden during pandemic period among the Asian countries, and ranked 2 nd in the world, after Austria (Sarkodie \& Owusu, 2021).

Unemployment and deaths are the most critical social consequences of the COVID-19 pandemic. In terms of unemployment rate, Malaysia recorded the highest compared with Singapore and Taiwan. As at April 2021, Malaysia recorded a $4.6 \%$ unemployment rate as compared with Singapore (2.9\%) and Taiwan (3.71\%) (Trading Economics, 2021). This is the result of the prolonged lockdown imposed by the Malaysian government, which had a significant impact on the national economy. Nevertheless, the unemployment rate for Malaysia decreased by $0.4 \%$, that is, from 5\% in April 2020 to 4.6\% in April 2021 (Trading Economics, 2021). This is the positive outcome of implementing the above-mentioned economic stimulus packages by the Malaysian government in reviving the economic activities.

With reference to Fig. 1, Malaysia reported the highest death rate owing to the high number of confirmed COVID19 cases compared with the figures of Taiwan and Singapore as at 30 April 2021. The total deaths in Malaysia, Taiwan and Singapore are 1506, 12, 30 respectively (Our World in Data, 2021). This indicates that the measures taken by Malaysia have not been very successful in reducing COVID-19 related deaths so far. One possible main reason is that many people staying in Malaysia are yet to be vaccinated. For instance, only 552,862 out of 32 million people had completed both doses of the vaccine as at 30 April 2021, which works out to only $1.73 \%$ of the population (The Star, 2021). The section below provides an analysis of the success-enabling and successdisabling factors of the Malaysian government in combating the COVID-19 pandemic thus far.

\section{Success-Enabling and Success-Disabling Factors}

\section{Success-Enabling Factors}

When the number of COVID-19 cases rising significantly since 14 March 2020, the Malaysian government implemented the MCO from 18 March to 3 May 2020 (Refer to Fig. 2). Thankfully, the MCO successfully broke the chain of COVID-19 infection in Malaysia on 29 April 2020 with the lowest national daily cases figure (two-digit number) reported since the enactment of the MCO, and the recovery rate was at 68.91\% (Kaos, 2020; Kaos \& Chung, 2020). In terms of 
Cumulative confirmed COVID-19 deaths vs. cases, Apr 30, 2021

The number of confirmed cases is lower than the number of total cases. The main reason for this is limited testing. The grey lines show the corresponding case fatality rates, CFR (the ratio between confirmed deaths and confirmed cases).

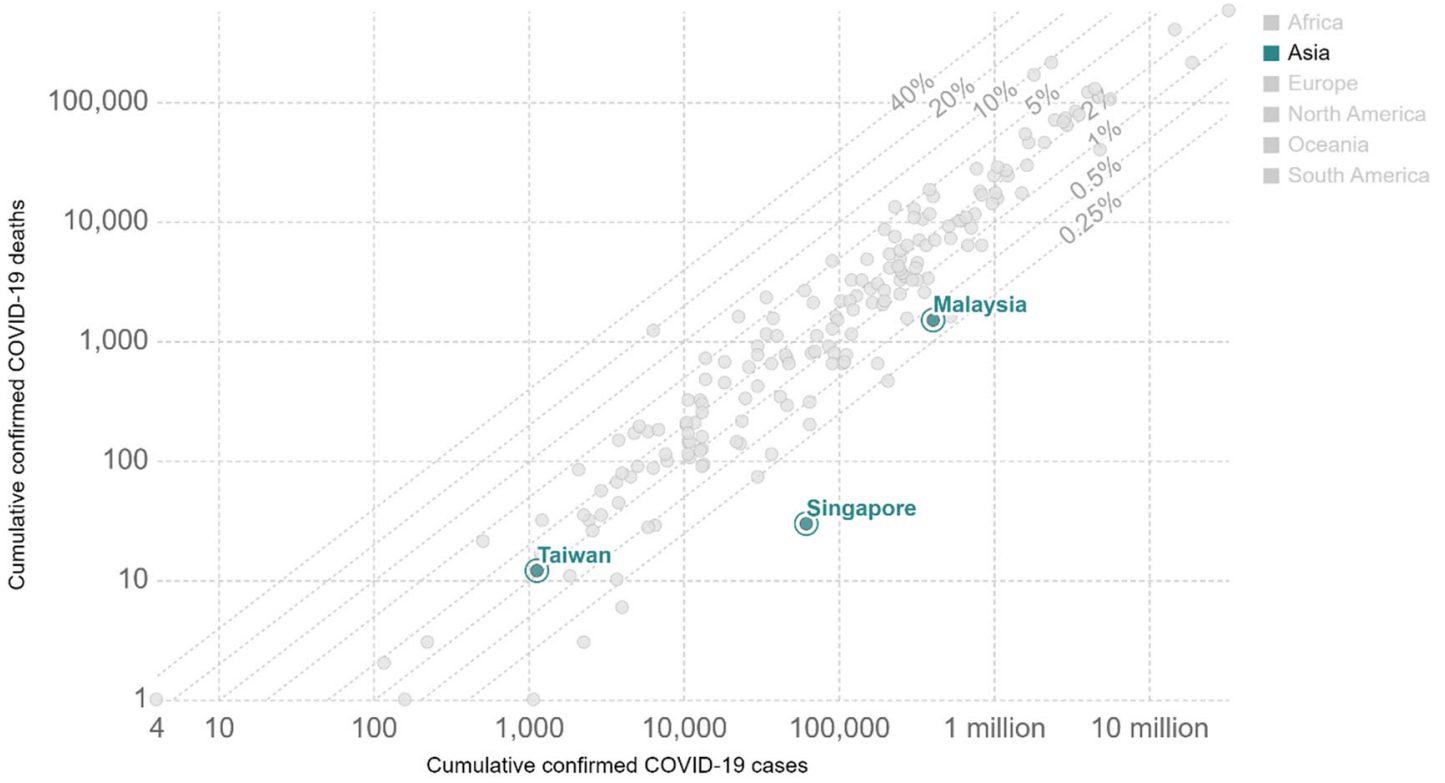

Source: Johns Hopkins University CSSE COVID-19 Data - Last updated 17 June, 06:02 (London time) OurWorldlnData.org/coronavirus • CC BY

Fig. 1 Cumulative COVID-19 deaths and cases for Malaysia, Singapore and Taiwan as at 30 April 2021. Source: Our World In Data (2021)

\section{New cases}

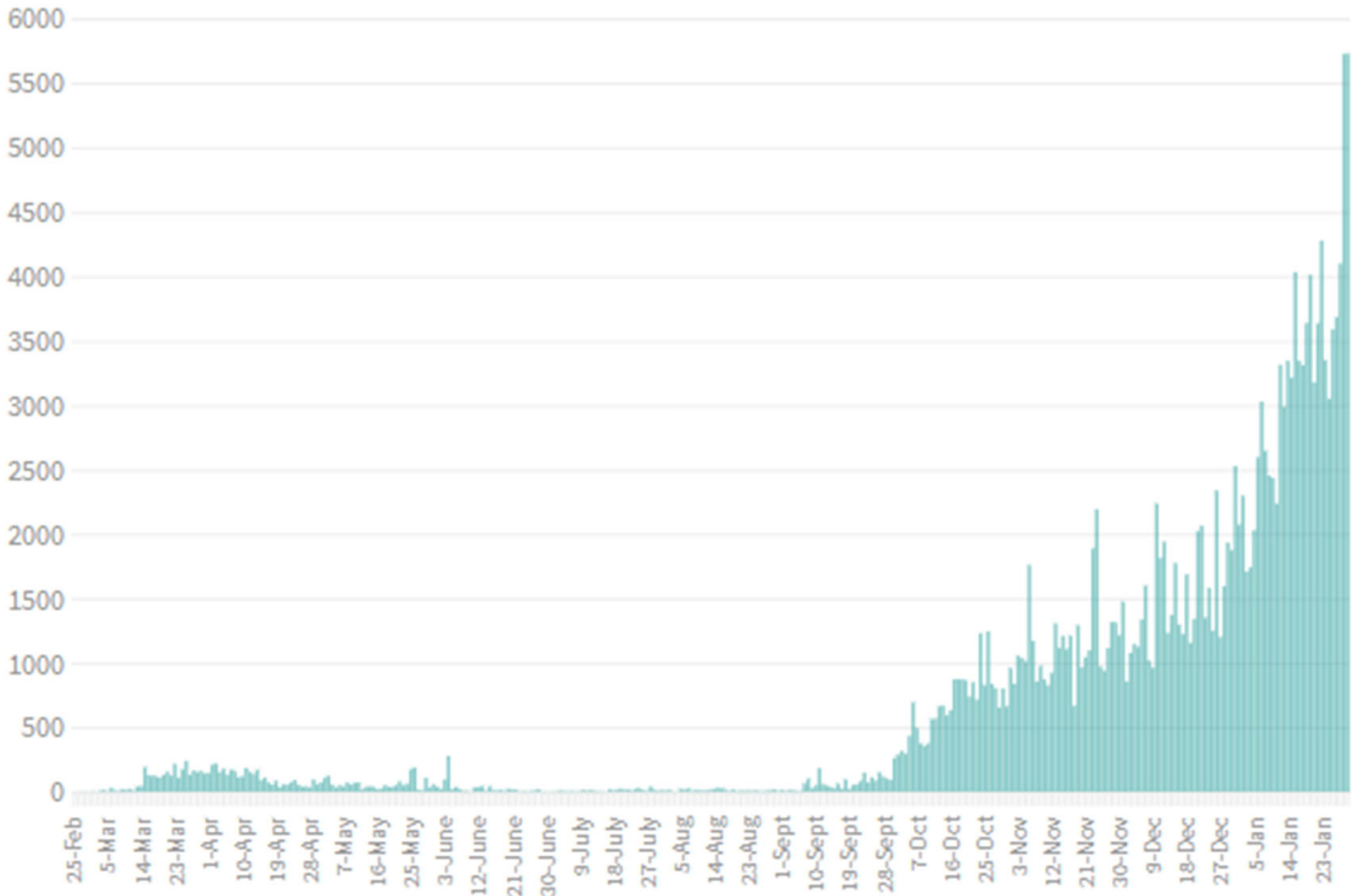

Source: Health Ministry - Active cases means total confirmed cases minus deaths and recoveries.

TheStar

Fig. 2 Daily confirmed cases of COVID-19 in Malaysia from 25 February 2020 to 30 January 2021. Source: Profdten and Ahmad (2021) 
recovery rate, Malaysia ranked 4th among the ASEAN countries as at 29 April 2020 - Cambodia (97.54\%), Brunei (89.95\%), Vietnam (83.33\%), Malaysia (68.91\%), Laos $(36.84 \%)$, Indonesia (13.18\%), Philippines $(12.25 \%)$, Myanmar (10.67\%) and Singapore (7.54\%) (Fevre, 2020). As the number of confirmed cases decreased, the government relaxed the regulations, and the $\mathrm{MCO}$ was replaced with CMCO from 4 May until 9 June 2020. Since the number of positive cases was under control during the $\mathrm{CMCO}$, the government replaced the $\mathrm{CMCO}$ with the $\mathrm{RMCO}$ from 10 June to 31 August 2020; domestic travelling or religious gatherings were permitted, the aims of which were to put the national economy on a recovery path and improve the social wellbeing of the people.

During the MCO, the government shut down non-essential businesses and schools, banned outdoor sports or activities, imposed regulated travel bans, and 14-day mandatory selfquarantine in $\mathrm{MoH}$-designated places for those entering Malaysia (Kaur, 2020). All foreigners or tourists were barred from entering the country to minimize the imported cases (Prime Minister's Office of Malaysia, 2020). This movement control is similar to those of Taiwan and Singapore. These two countries imposed mandatory quarantine for anyone who entered their land, which successfully curbed the transmission of the virus. As a collective society, Malaysians in general adhere to reasonable instructions from the government as the benefits are clearly explained. Malaysia government also introduced strict enforcement of roadblocks to curb unauthorized travel and ensure people comply with SOPs; penalties were handed down to those who failed to abide by the rules - up to RM1000 fine or/and a jail term of not more than six months (Tanzizi, 2020). As reported by Timbuong (2020), the Royal Malaysia Police worked with the Malaysian Armed Forces to conduct roadblock operations at key points along the main roads throughout Malaysia, the purposes of which were to prevent unauthorized inter-state and inter-district traveling or traveling of more than $10 \mathrm{~km}$ from home. People were only allowed to travel within $10 \mathrm{~km}$ from their homes to purchase necessities (Rahim, 2020). As at 9 April 2020, the Royal Malaysia Police had issued 95 summonses with RM1000 fines to those who travelled more than $10 \mathrm{~km}$ from home without a working permit from the companies (Palansamy, 2020). High penalties are an effective tool to stop people from going out needlessly, and hence can limit the spread of the virus. Like New Zealand, Malaysia imposed a full-scale lockdown for the whole nation during the early stage of the COVID-19 outbreak, and enforced strict laws to ensure the people obeyed the instructions. However, Western European countries such as Germany and France imposed partial lockdowns during the early stage of the COVID-19 outbreak. In France, the schools stayed open and outdoor sports were allowed (Thiessen, 2020). Compared with the RM1000 (USD 241) fine imposed by the Malaysian government, the French imposed $€ 135$ fine
(USD 164) (Palansamy, 2020; Thiessen, 2020). In Malaysia, the minimum monthly salary is approximately RM1200, and the RM1000 fine is more than half of the wage - a pretty heavy fine in compelling individuals to stick to the governmentmandated restrictions (Ashley, 2020). Meanwhile, the minimum monthly salary in France is around $€ 1500$; the $€ 135$ fine is a small fraction of the pay (Perlman, 2019). Consequently, France recorded a total of 129,584 COVID-19 confirmed cases in the country, while Malaysia only recorded 6002 cases as at 30 April 2020 (Worldometers, 2021a, 2021b). Nevertheless, The WHO indicated that France offered the most comprehensive overall health care in the world for the year 2020 (World Health Organization, 2020).

In terms of risk communication, the $\mathrm{MoH}$ works with the Malaysian National Security Council (NSC) to disseminate daily updated information about COVID-19 to a broader public through various media. For instance, the $\mathrm{MoH}$ has created CRPC KKM Telegram and Facebook pages such as Kementerian Kesihatan Malaysia (Ministry of Health) and Crisis Preparedness and Response Centre (CRCR) (Kaur, 2020; Shah et al., 2020). The CRCR is similar to Taiwan's CECC that facilitates communication related to COVID-19, to ensure the pandemic information is transparent and available to the public daily. With the free flow of data, people will feel more confident about the government's ability to curb the transmission of the virus, and allay the fear of out-of-control conditions. A mobile app, MySejahtera was launched in April 2020 in Malaysia; the public can use it to scan the QR code when entering any premise. In addition, the app provides various pieces of the latest information: statistics of COVID-19 cases in the country and respective states; places that the infected patients had visited; locations of nearest health facilities, and health guides (Malaysia Communications and Multimedia Commission, 2020). This is similar to the TraceTogether app launched by the Singapore government with similar features to track suspected carriers of COVID19 (Ungku, 2020).

Malaysian government implemented social distancing SOPs during the pandemic outbreak. To decrease the risk of infection, people must maintain a minimum of a one-meter separation between each other. Shops or offices have to place the " $1 \mathrm{~m}$ " marking on the floor to guide customers on queuing distance. $\mathrm{MoH}$ encourages no handshake practices in the workplaces and maintains a one-meter physical space between workers (Ministry of Health Malaysia, 2020). During CMCO, dined is allowed in the restaurant or café but limited to twoperson per table to prevent infection (Anis, 2020). The onemeter separation between each other and workplaces social distancing are also implemented in other countries such as Singapore, Taiwan, France, and Germany. It is not a norm to practice social distancing either in high-context or low-context cultures. For high-context cultures such as Singapore, Taiwan, and Malaysia, people valued collectivism and believe that the 
government is working for the community's good (Kim et al., 1998). As therefore, most people follow the social distancing SOPs as they are afraid of the heavy fines. Meanwhile, people in low-context cultures countries value personal interests and individuality. For low-context cultures such as France and Germany, they act based on their beliefs on the best way to proceed (Kim et al., 1998). For example, people in France still hang out in parks and outside cafes after the government announced a lockdown and encouraged people to stay at home (Baker, 2020).

On the education front, the Ministry of Education introduced online learning for the students due to the closure of all schools and universities (Povera \& Yunus, 2020). This policy is similar to those of Taiwan and Singapore, with the aim of preventing mass gathering and reducing the risk of infection. The curve was flattened since 29 April 2020, and this demonstrated that the MCO with SOPs implemented by the government was producing a positive result (Kanyakumari, 2020; Tan, 2020). In comparison, the pre-MCO model simulation highlighted that the MCO could minimize the number of active COVID-19 cases by $99.1 \%$ (Gill et al., 2020). Malaysia succeeded in flattening the infection curve of COVID-19 on 17 May 2020 (Song \& Ling, 2020). The situation further improved with an affirmation that there was only one imported case reported on 1 July 2020, the lowest figure since the MCO was imposed, and the number of infected cases remained in two digits until 7 September 2020. In brief, the underlying success of Malaysia in combating the pandemic at the early stage was attributed to various enabling factors: total lockdown, closing of borders, mandatory quarantine, heavy fines for not following SOPs, risk communication via social media, social distancing, and online learning.

\section{Success-Disabling Factors}

The third wave of COVID-19 started in September 2020 with the number of positive cases increasing sharply and hitting three digits on 8 September 2020. The number of daily COVID-19 new cases was on the rise from 8 September 2020 until 30 January 2021. As shown in Fig. 2, Malaysia reported more than 1000 new daily cases for the first time on 24 October, with 1228 cases; and more than 2000 cases on 24 November 2020, with 2188 cases. Unfortunately, Malaysia hit more than 3000 daily new cases, with 3027 confirmed positive, on 7 January 2021, which escalated to 4029 cases within two weeks, on 16 January 2021. Fearing further rise, the government reintroduced the MCO on 13 January 2021. There was a sudden surge of COVID-19 cases even though Malaysia had successfully controlled the infectious disease in the second quarter of 2020 as mentioned above, why? What caused the COVID-19 active cases trending upward again? The paragraphs below critically analyze the sudden spike of COVID-19 cases from September 2020 to April 2021.
The spike of COVID-19 cases since September 2020 was triggered by an election in the Sabah state (East Malaysia); people who were infected during the time travelled back to West Malaysia after the election (Geraldine, 2020). This happened as the politicians were having mass gatherings without following the SOPs - many of them did not wear face masks and did not observe social distancing during the election campaign period (Sukumaran, 2020). This scenario was different from that of Singapore when the country held the general election on 10 July 2020 with strict adherence to SOPs. The political party leaders were only allowed to run the online campaigns as all mass gatherings and physical rallies were banned (Murad, 2020). To safeguard the voting citizens' safety, the election department formulated various contingency plans such as strict SOPs on hygiene, different timing of voting following the age groups (high-risk group and low-risk group), social distancing in the voting centers, reducing the number of voters for each station, and extension of polling hours (Government of Singapore, 2020). There are a vast number of dissimilarities between Singapore and Malaysia when it comes to handling the SOPs for the election during the COVID-19 period; the loose SOPs practiced in the Sabah election led to another wave of infection in Malaysia.

There was also an epidemic of COVID-19 in the Sabah detention centers, where the undocumented immigrants from the Philippines and Indonesia were kept in October 2020. This happened due to the overcrowding in the lock-ups, and the state government failed to practice social distancing for the detainees (The Straits Times, 2021). In November 2020, the Teratai cluster that was linked to Top Glove Corporation, the world's biggest glove manufacturer, caused more than 1000 infected cases, most of whom were foreign workers (Salim, 2020). The lack of compliance with the SOPs in the manufacturing sector and the absence of clear SOPs were the main reasons that had led to an increase in the number of COVID-19 cases. Shankar (2021) posited that these companies' human resource departments failed to follow the SOPs, and the government authorities did not closely monitor the situations. An estimated 3 million documented and undocumented migrant workers are affected by the pandemic, in one way or another (Lim, 2020a). On the other hand, Singapore reported that almost $47 \%$ of the foreign workers had been infected with COVID-19; however, the Ministry of Manpower came out with clear SOPs during mid2020 for the business and industrial sectors to slow down the transmission (Lim, 2020b). Here are some examples of the procedures: compulsory systematic testing for all the foreign workers; maintaining a high standard of the hygiene conditions in the workers' dormitory; and employer-provided transportation from the workplace to the dormitory. These are some of the differences between Singapore and Malaysia in handling the migrant workers. To sum up, Malaysia has not been taking proactive actions in formulating strict SOPs and executing them accordingly during the early stage of infection. 
Another reason for the spike of COVID-19 cases again is the lack of enforcement of the laws. This can be observed through the numbers of people arrested for not following the COVID-19 SOPs. Notably, 4189 people were arrested for defying the MCO as at 1 April 2020, but only 674 people were detained during the RMCO as at 11 October 2020 (Bedi, 2020a, 2020b). Comparing the total population of the two countries, Malaysia has a total 32.69 million population while Singapore only has a 5.69 million population (Department of Statistics Malaysia, 2020a; Department of Statistics Singapore, 2020). Singapore has a smaller population but issued a higher number of fines - 6600 as at 1 July 2020; and 140 working passes of migrant workers were revoked for failing to follow the SOPs. There is also a double standard in meting out punishments - a minister escaped prosecution even though the person breached the quarantines rules (Jaipragas, 2020). Collectively, it can be demonstrated that Malaysia has been lacking in enforcement of laws, and the authorities have not been consistent in executing the laws in the society.

The living conditions of certain groups of people have also contributed to the high number of COVID-19 cases, which can be grouped into three categories. The first is cramped accommodations of rented properties, which have been converted into multiple cubicles or rooms (Bong, 2021). One property might house as many as four or five households, which work out to as many as 20 people in it. Overcrowded living spaces and poor hygiene contributed to the spreading of COVID-19. For example, the people-packed rented properties of Sibu Jaya Flats in Malaysia caused 1079 COVID-19 positive cases on 23 March 2021 (Dayak Daily, 2021b). The second is the longhouses in the states of Sarawak and Sabah, Malaysia; the household units of which are built in close proximity. A longhouse is a stilted timber building with one section divided into a series of individual family rooms, and the other utilized as an open communal area for social gathering. By sharing the common areas with a large number of households, it is difficult to practice social distancing, and hence the chances of infection increase. This space problem led to the occurrence of more than 2000 COVID-19 positive cases as at 9 March 2021 (Dayak Daily, 2021a). The third is foreign employees are housed in overcrowded dorms, which serve as breeding grounds for the coronavirus (Bernama, 2020a). Due to the extreme confined spaces, there was little room for social distancing among the workers. The poor living conditions contributed to the increase in COVID-19 cases in Malaysia. For instance, more than 5000 positive cases occurred in the overcrowded workers' dorms of Top Glove Corporation in Malaysia as at 30 November 2020 (Hassan, 2020).

To overcome the aforementioned issues, the Malaysian government introduced the enhanced MCO (EMCO) in the infected areas. When an area is declared as EMCO, barbed wire fencing will be installed around the affected area, which is meant to control the movements of the people. Permanent and temporary residents of the infected living places are not permitted to leave their houses, and non-residents are not permitted to enter the area (Hassan et al., 2021). The EMCO is effective in curbing the spread of COVID-19, as it limits people movement in a high-risk area, and reduces the infection rate. It also facilitates early detection of positive cases, screening, and curbing the spread of COVID-19 among the residents. The battle against COVID-19 is still ongoing in Malaysia. For instance, in Sarawak state alone, there were 50 areas under EMCO as at 29 April 2021 (Sarawak Disaster Management Committee, 2021).

In summary, the spike of positive cases in Malaysia from September 2020 to April 2021 was attributed to several factors: failures to follow the SOPs during the Sabah state election; the lack of enforcement of the laws, that is, allowing mass gathering during the $\mathrm{MCO}$ for some events; slow in taking actions in handling the outbreak of infection among undocumented immigrants and foreign workers; and poor living conditions of certain groups of people. This raises a question: Can we replicate Singapore's COVID-19 success model in Malaysia or other Asian countries with high daily new cases? In a longer term, the COVID-19 pandemic is not merely hurting the economy and people's livelihoods, it will also affect the people's mental health adversely. The implications of the pandemic to the society will be discussed in the next section.

\section{Implications of COVID-19 for Society}

\section{Mental Health}

There is a change in the standard and manner of human interaction due to the pandemic that will affect people's social wellbeing; for instance, self-quarantine and social distancing. A study conducted by The Centre Malaysia from 5 April to 10 April 2020 among local people residing in Malaysia indicates that $48 \%$ of the respondents (Malaysians aged 18 and above) experienced anxiety, and $45 \%$ showed signs of depression during the MCO (Azuddin \& Zakaria, 2020). The study was conducted during the MCO period with peak daily cases recorded at 235. Using the Depression Anxiety Stress Scales (DASS) questionnaires, the online survey was assisted by a consultant psychiatrist. The DASS measures an individual's emotional well-being in three aspects, namely depression, anxiety and stress (Azuddin \& Zakaria, 2020). The survey results indicate that many Malaysians experienced high levels of negative emotions and depression during the first introduced lockdown.

The country's economic upheaval and uncertain future during the pandemic period fueled worries and chronic anxieties, 
which could lead to cognitive deterioration (Hassandarvish, 2020; Shanmugam et al., 2020). The public cannot foresee how the pandemic would pan out or how the government would formulate or change policies from time to time to deal with the current perilous situations. The employers are concerned that the country can come under the MCO anytime, sometimes quite abruptly, when the number of confirmed positive cases increases. Reintroducing the MCO could lead to the closing of specific businesses or industries, whereas the employers need to continue to bear the fixed costs of the business operations such as rent or workers' salary, even though there is reduced revenue or none at all. The employees are worried about the future of the companies they work for and wonder if they would lose their jobs. All these concerns could generate lots of fears in the people's minds and even cause panic attacks, especially when the pandemic appears to be out of control. Besides, social distancing could disrupt the people's social rhythm and work routines; loneliness as well as feeling of hopelessness and worthlessness could easily set in, and in extreme cases, might lead to suicide attempts (Gunnell et al., 2020; Holmes et al., 2020). It is a difficult and poignant situation when people are away from families, facing the uncertainty of their jobs or financial sources, and have no one to talk to. Holt-Lunstad et al. (2015) reported that the mortality rate for those suffering from severe social isolation could be as high as $29 \%$. Social distancing and wearing face masks stop people from getting close to each other, depriving them of lots of friendly gestures such as shaking hands or seeing the smiley faces. Some people might be isolated during the pandemic and they have nobody to share their feelings with, and on top of that, people around them cannot observe their feelings because of the face masks; this is very dangerous and the possibility of suicide cannot be ruled out (Hwang et al., 2020).

For the person under investigation (PUI), the person under surveillance (PUS), and patients tested positive for COVID19 , the isolation could induce negative psychological emotions within them. Murugappan (2020) highlighted that these groups of people could experience post-traumatic stress disorder (PTSD). In Malaysia, one PUS who was confined to a quarantine center had vandalized the room, and another PUI committed suicide (Chua, 2020; Zolkepli, 2020). The swab test, the fear of being tested positive for COVID-19, and social stigma heighten the anxiety level among the PUS. Patients who recovered from COVID-19 live under tremendous stress, worrying about the risk of re-infection as some recovered patients had tested positive again during the follow-up health checks (Vanar, 2020). Self-quarantine and social distancing have a more significant impact on specific groups of people who are emotionally vulnerable, for example, those with a borderline personality disorder or psychiatric disorders (Chong, 2020; Gunnell et al., 2020). The hospital staff members and frontline workers are busy copping the pandemic, and these particular groups of people cannot get close to others because of the nature of their jobs; besides they receive little attention from the health authority. These working and social conditions do not augur well for the above groups of people; over a prolonged period, negative emotions might slip in such as anxiety, fear, and even depression.

By exposing to long-term stressors and job demands, the front-liners may experience burnout, develop psychological fatigue, and eventually exhibit poor work performance. In a recent study, Malaysia's frontline workers were apart from their families for months (Nienhaus \& Hod, 2020). Most of them felt stressed and depressed as the public saw them as "infected persons" due to their working environment. Frontline workers are required to work extra hours to cope with the massive number of infected patients. Most of them are tired of overwork, under job pressure, and scared of facing patients with the deadly virus. All these factors can stimulate mental stress and cause insomnia, which will adversely affect their work performance. These scenarios are highlighted in Tan (2021b) report indicating that some of the frontline workers have suffered from depression and resorted to relying on antidepressants as the negative emotions become unmanageable.

Woon et al. (2020) pointed out that students' stress and anxiety levels were elevated after the MCO was lifted; they were fearful of the long-time exposure to the high-risk learning environment. Higher education students who were away from home and had difficulty switching to online learning also experienced a high level of anxiety during the COVID-19 outbreak (Grubic et al., 2020). The online learning has its challenges - unstable Internet connection, limited data capacity, or lack of proper electronic devices (Borneo Post, 2021). Consequences of measures taken by the government, such as social distancing, uncertainty in school commencement, delay in examination, and necessity of online learning, have increased the perceived threats in the people's minds, which in turn led to mental depression among university students in Malaysia (Sundarasen et al., 2020). The students' mental health and wellbeing are at stake with the constant fear and anxiety about a bleak future. To elaborate more, Sundarasen et al. (2020) elucidated that more than $30 \%$ of university students in Malaysia felt anxious during the pandemic between April and May 2020.

\section{Job and Domestic Violence}

Social capital is a more influential driver of the society's wellbeing compared with economic wealth in the South Korea context (Lee \& Kim, 2018). However, the looming COVID-19 economic havoc has caused socioeconomic distress followed by mass unemployment. Beja (2019) illustrated that the indirect cost of unemployment is twice higher than the direct cost of subjective wellbeing, which leads to a reduction 
in social society participation and an increase in personal violence. Many enterprises in Malaysia are providing unpaid leave, reducing the workforce's size, cutting wages, or even closing down due to the economic costs of COVID-19 (Shanmugam et al., 2020). For instance, Genting Malaysia has cut $15 \%$ of its workforce (Ngui \& Chew, 2020). Social Security Organizations and Employment Insurance System reported that the job losses have increased by $42 \%$ in Malaysia, in the first quarter of 2020 (Bernama, 2020b). Consequently, the unemployment rate rose to $5.3 \%$ in May 2020, and was expected to rise to $8 \%$ by the end of 2020 (Murugiah, 2020). Department of Statistics Malaysia (2020b) pointed out that $52.5 \%$ of Malaysians were financially affected during the MCO, and the Central Bank of Malaysia estimated roughly 951,000 people would face unemployment (Khalid, 2020). The loss of income and anxiety of uncertainty led to a more aggressive character for those pre-existing aggressors. As a result, as at 26 March 2020, the number of domestic violence cases spiked with call-ins increased by $57 \%$ or 1893 calls from women in distress, via Talian Kasih (Caring Hotline) in Malaysia (Arumugam, 2020; Hassandarvish, 2020). From 18 March to 30 April 2020, 526 investigation papers were opened in connection with domestic violence in Malaysia (Baharin, 2020). During the lockdowns, there is limited access to and assistance from the support structures for domestic violence victims. The majority of women are forced to stay at home with their aggressors for longer than usual due to these factors: travel restrictions, working from home, and kids learning from home.

In short, the COVID-19 pandemic led to health-related anxieties which could open up possibilities of suicides. The implementation of social distancing and lockdowns has produced adverse psychological outcomes. Self-quarantined persons had experienced PTSD, feelings of anxieties or depression. Due to the massive volume of chores in the workplace, many frontline workers experience burnout and they are in a state of depression. The students feel stressed and anxious; they have to cope with the uncertainties and challenges of new teaching mode - from classroom to online.

\section{Volunteering and Mental Wellbeing Benefits}

Amid the anxiety, stress, and fear, it seems the COVID-19 might have engendered changes in the people's attitudes towards volunteering. Trautwein et al. (2020) conducted a study on volunteering during the lockdown using an online survey of 565 COVID-19 volunteers in Switzerland from 6 May 2020 to 3 June 2020. The study reveals that the fulfilment of the self-enhancement motive and value motive positively affected the volunteers' satisfaction. There have been several studies done showing that volunteering is not just about giving, but also gaining mental wellbeing benefits; increased life satisfaction through established social ties; counteracting negative emotions; and reducing anxieties (Thoits \& Hewitt, 2001; Tierney \& Mahtani, 2020; Veerasamy et al., 2013; Wilson, 2012). With the social distancing measures, volunteers' roles have extended to runner services such as medicine delivery and buying groceries for the most vulnerable, with the panic buying chaos going on (Etkind et al., 2020). In Malaysia, the $\mathrm{MoH}$ indicated that more than 1000 retired nurses and 2300 volunteers had joined the frontline workers during COVID-19 (Zainul, 2020). Volunteer tailors and non-governmental organizations (NGOs) around Malaysia helped produce personal protective equipment for the frontline workers (Shah et al., 2020). Besides, the civil society campaign - \#kitaJagakita (We care for each other) was started by a group of Malaysian volunteers to support society by matching people who want to help with people who need the help (Teoh, 2020).

The positive emotions from volunteering can reduce the negative emotions such as fear or anxiety due to the pandemic (Tierney \& Mahtani, 2020). Volunteering offers a chance for people to support and contribute to the society in the pandemic period. Helping others during their difficulties can increase a person's self-confidence and give a sense of identity of pride. In a nutshell, the COVID-19 pandemic leads to reflection and rethinking of what volunteers and social purpose organizations can do for the society, hence, creating a volunteering society. The next section discusses the PEST analysis.

\section{PEST Analysis}

To provide insights into practitioners, the PEST analysis is presented in Table 1 below, with the lessons learned from Malaysia's experience while combating the COVID-19 pandemic. Based on the experience, recommendations are proposed for each aspect as well. For political factors, there is a full lockdown during the initial stage of the COVID-19 outbreak, imposition of heavy fines and strict enforcement of laws, and running elections during the Covid-19 pandemic. Meanwhile, for economic factors, the analysis looks into the surge of the unemployment rate and residents' financial burden. In terms of social factors, mental health issues cropped up and the number of domestic violence cases spiked during the pandemic period, which are discussed in the table. Lastly, the analysis covers technological factors such as online learning and introducing the mobile application for COVID-19 purposes.

\section{Final Thoughts}

As a concluding remark, at the point of writing this paper, Malaysia has experienced some degrees of success and failure in the national effort of fighting the COVID-19 pandemic. By 
Table 1 PEST Analysis for COVID-19

Factors $\quad$ Lessons learned from Malaysia's Experience Recommendations

Political

Full lockdown during the initial stage of COVID-19 outbreak

Imposition of heavy fines and strict enforcement of laws

Running election during COVID-19

Residents' financial burden

\section{Social \\ Mental Health Issues}

Spike in domestic violence cases during the pandemic

Economic

Surge of unemployment rate
As at 29 April 2020, Malaysia achieved a recovery rate of It is essential to enforce a full lockdown to prevent crowd about $69 \%$, which ranked 4th among the ASEAN countries (Kaos, 2020).

Malaysia introduced strict enforcement of roadblocks and handed down penalties to curb unnecessary travel-- a compound fine of RM1000 for breaching MCO-related rules and standard operating procedures (Tanzizi, 2020).

Malaysia recorded a spike of COVID-19 positive cases since September 2020 due to an election in Sabah state (Geraldine, 2020). Politicians held mass gatherings and the government authority failed to enforce social distancing among voters.

Wage subsidy program 2.0 to support businesses faced with revenue reduction; ensure employees receive reasonable wages and minimize layoffs during the pandemic (The Star, 2020).

Introduced Prihatin Rakyat Economic Stimulus Package (PRIHATIN), National Economic Recovery Package (PENJANA), and KITA PRIHATIN Package (The Star, 2020).

rontliners started to burn out with job demands, developed psychological fatigue, and eventually led to poor working performance (Nienhaus \& Hod, 2020).

From 18 March to 30 April 2020, 526 investigation papers were opened in connection with domestic violence in Malaysia (Baharin, 2020). gathering and slow down the COVID-19 spreading. However, the government must give clear instructions, standard operating procedures and guidelines on the lockdown measures to avoid confusion and panic among the people.

The heavier fines are intended to act as a deterrent and not to add additional burden to individuals who are already severely impacted by the COVID-19 pandemic. This has serious economic and social ramifications. Greater clarity on the standard operating procedures of dos and don'ts must be communicated to the general public prior to the implementation to avoid confusion.

Postponing election is the most responsible action to protect the public health during the COVID-19 pandemic. Institute for Democracy and Electoral Assistance reported that 68 countries and territories have postponed national or local elections between 21 February 2020 and 26 July 2020.

Providing financial aid is a short-term solution to mitigate the economic impacts of COVID-19. In the long term, the government should provide training or upskill programs for the unemployed. People can master a skill to get a job and not rely on government support all the times.

The limitations of the economic packages are that they do not include everyone in the society and address a range of different aspects of people's lives. The economic packages should cover everyone in the society from corporates to individuals. All-day childcare should be provided for free to frontliners' children. There should be double relief for single parents and child supplements should be provided. For non-profit organizations, the government can introduce a special loan program to help them remain operational during the pandemic. Funds should be allocated for investment in the future such as digital schools or all-day childcare centers.

Confidential mental health and psychosocial support services must be made available to frontline workers. In case of crises, the frontliners should have access to psychotropic medications and mental healthcare facilities. Then, it is significant to encourage peer support or establish a buddy system. This can assist inexperienced frontliners and they can speak to people that understand their conditions. Employers should respect their workers' rest hours and off days. Employers can also implement "flexi-time" and "flexi-load" of which shifts are shared by a few teammates.

The government must provide efficient support to survivors of violence such as shelters, hotline and counselling. The national hotline should be available $24 \mathrm{~h}$ to ensure the victims can reach the authorities. There is a need to develop innovative methods for reporting violence. For example, code words on 
Table 1 (continued)

\begin{tabular}{|c|c|c|}
\hline Factors & Lessons learned from Malaysia's Experience & Recommendations \\
\hline & & $\begin{array}{l}\text { helplines. Government should partner with } \\
\text { international organizations or civil society } \\
\text { organizations by enlisting the services of those } \\
\text { organizations during the pandemic. }\end{array}$ \\
\hline \multicolumn{3}{|l|}{ Technological } \\
\hline Online learning & $\begin{array}{l}\text { Students switching to online learning are faced with high } \\
\text { level of anxiety due to unstable internet connection, } \\
\text { weak or no connection in certain areas (Borneo Post, } \\
\text { 2021). }\end{array}$ & $\begin{array}{l}\text { Airing schools' lessons via all-day educational television } \\
\text { can help students with no access to online home-based } \\
\text { teaching and learning. However, parental guidance and } \\
\text { monitoring are important to ensure that they do not } \\
\text { switch to other channels. }\end{array}$ \\
\hline $\begin{array}{l}\text { Introducing the mobile } \\
\text { application to keep track of } \\
\text { suspected carriers for } \\
\text { COVID-19 }\end{array}$ & $\begin{array}{l}\text { A mobile app, MySejahtera was launched in April } 2020 \\
\text { in Malaysia; the public can use it to scan the QR code } \\
\text { when entering any premise; users can obtain the latest } \\
\text { information: statistics of COVID-19 cases, places that } \\
\text { the infected patients visited, location of nearest health } \\
\text { facilities, and health guides (Malaysia } \\
\text { Communications and Multimedia Commission, 2020). }\end{array}$ & $\begin{array}{l}\text { There should be a live chat function in the mobile } \\
\text { application to ensure people can get the right } \\
\text { information instantly from the right source. This can } \\
\text { prevent people from getting information from } \\
\text { unreliable source during the pandemic. To combat fake } \\
\text { news, the application can consider integrating social } \\
\text { media features for people to obtain information during } \\
\text { the pandemic. It is also recommended that the mobile } \\
\text { application include information pertaining to exposed } \\
\text { location, date and time visited by COVID-19-positive } \\
\text { persons. This is to alert other people who have visited } \\
\text { the same location, at a specific time and on a specific } \\
\text { day, and go for tests if necessary. }\end{array}$ \\
\hline
\end{tabular}

Technological

Online learning

suspected carriers for

COVID-19
Students switching to online learning are faced with high 2021).

mobile app, MySejahtera was launched in April 2020 in Malaysia; the public can use it to scan the QR code when entering any premise; users can obtain the latest information: statistics of COVID-19 cases, places that acilities, and health guides (Malaysi Communications and Multimedia Commission, 2020). helplines. Government should partner with international organizations or civil society on enlisting the services of those organizations during the pandemic. monitoring are important to ensure that they do not information instantly from the right source. This can prevent people from getting information from news, the application can consider integrating social media features for people to obtain information during the pandemic. It is also recommended that the mobile application include information pertaining to exposed . the same location, at a specific time and on a specific day, and go for tests if necessary. and large, COVID-19 has impacted the society both positively and negatively. In the year 2020, a slew of key research associated with COVID-19 has been conducted particularly in the epidemiological, medical, and virological realms. Hence, there is an urgent need to carry out empirical research on social wellbeing related to the COVID-19 pandemic. Several aspects should be addressed in the future investigations: How do social distancing policies impact the landscape of social lives? Will the post-COVID-19 environment reset the standard of social happiness and wellbeing in high-context cultures? To what extent and in what manner does the volunteering during COVID-19 affect the psychological distress and life satisfaction in high-context cultures? The research ideas presented in this paper are by no means exhaustive; however, we believe these notions are likely to help future researchers to formulate problem statements and refine research questions in the social wellbeing domain. Exploring the above research questions should yield substantive and meaningful findings that can uncover the impacts of COVID-19 on various aspects of the society's wellbeing. Lastly, we hope more studies can be carried out in the Asian countries so that the COVID-19 pandemic can be investigated in different contexts and from different perspectives. This will enable useful and generalizable findings be shared among the research fraternity. Using substantially the "Western, Educated, Industrialized, Rich, and Democratic" (WEIRD) samples, Henrich et al. (2010) noted that more social psychology research should be conducted in the under-represented regions such as Asian countries (high-context cultures).

Availability of Data and Material Not applicable.

Code Availability Not applicable.

\section{Declarations}

Ethics Approval Not applicable.

Consent to Participate Not applicable.

Consent for Publication Not applicable.

Conflict of Interest The authors declare that they have no conflict of interest.

\section{References}

Abdullah, J. M., Ismail, W. F. N. M. W., Mohamad, I., Ab Razak, A., Harun, A., Musa, K. I., \& Yeong, Y. L. (2020). A critical appraisal of COVID-19 in Malaysia and beyond. The Malaysian Journal of Medical Sciences, 27(2), 1-9. 
Anis, M. N. (2020). Dine-in allowed under conditional MCO but limited to two per table, says Ismail Sabri. The Star. Retrieved July 06, 2021, from https://www.thestar.com.my/news/nation/2020/10/13/ dine-in-allowed-under-conditional-mco-but-limited-to-two-pertable-says-ismail-sabri

Arumugam, T. (2020). MCO-linked domestic violence rises. New Straits Times. Retrieved April 20, 2020, from https://www.nst.com.my/ news/exclusive/2020/04/581233/mco-linked-domestic-violencerises

Ashley. (2020). New minimum wage gazetted. The Star. Retrieved June 21, 2021, from https://www.thestar.com.my/news/nation/ 2020/01/14/new-minimum-wage-gazetted

Aziz, N. A., Othman, J., Lugova, H., \& Suleiman, A. (2020). Malaysia's approach in handling COVID-19 onslaught: Report on the movement control order (MCO) and targeted screening to reduce community infection rate and impact on public health and economy. Journal of Infection and Public Health, 13(12), 1823-1829.

Azlan, A. A., Hamzah, M. R., Sern, T. J., Ayub, S. H., \& Mohamad, E. (2020). Public knowledge, attitudes and practices towards COVID19: A cross-sectional study in Malaysia. PLoS One, 15(5), $\mathrm{e} 0233668$.

Azuddin, A., \& Zakaria, I. (2020, April 28). MCO and mental well-being: Home sweet home? Part 1: Housing and crowding during the MCO. Retrieved July 05, 2020, from https://www.centre.my/post/mcoand-mental-health-living

Baharin, M. F. (2020). MCO sees spike in domestic violence cases. Bernama. Retrieved June 15, 2020, from https://www.bernama. com/en/general/news_covid-19.php?id=1843405

Baker, S. (2020). Western countries only seem capable of social distancing when their governments force them. Retrieved July 06, 2021, from https://www.businessinsider.com/coronavirus-westerncountries-bad-social-distancing-without-being-forced-2020-3

Bedi, R. S. (2020a). Ismail Sabri: 674 arrested for defying recovery MCO on Saturday (Oct 10). The Star. Retrieved January 20, 2021, from https:/www.thestar.com.my/news/nation/2020/10/11/ismail-sabri674-arrested-for-defying-recovery-mco-on-saturday-oct-10

Bedi, R. S. (2020b). Over 4,000 MCO arrests so far, says Ismail Sabri. The Star. Retrieved April 20, 2020, from https://www.thestar.com. my/news/nation/2020/04/02/over-4000-mco-related-arrested-sofar-says-ismail-sabri

Beja, E. L. (2019). Subjective well-being approach to valuing unemployment: Direct and indirect cost. International Journal of Community Well-Being,3(3), 277-287.

Bernama. (2020a). Cramped living space, poor hygiene cause of Covid19 infection among foreign workers - Health DG. The Edge Markets. Retrieved June 26, 2021, from https://www. theedgemarkets.com/article/cramped-living-space-poor-hygienecause-covid19-infection-among-foreign-workers-\% E2\% $80 \% 94$ health-dg

Bernama. (2020b). Socso: Job losses increase by 42pct in Q1. New Straits Times. Retrieved July 25, 2020, from https://www.nst.com.my/ news/nation/2020/06/597702/socso-job-losses-increase-42pct-q1\#: $\sim:$ text=KUALA \% 20 LUMPUR \% 3 A \% 20 Due \% 20 to \% 20the,Employment\%20Insurance\%20System\%20(EIS).

Bong, K. (2021). Cramped rented properties contribure to increase Covid-19 cases in Tiong Hua, Sibu Jaya flats. Dayak Daily. Retrieved June 27, 2021, from https://dayakdaily.com/crampedrented-properties-contribute-to-increase-covid-19-cases-in-tionghua-sibu-jaya-flats/

Borneo Post. (2021, January 23). Are we all ready to succeed in our online learning? Borneo Post. Retrieved June 27, 2021, from https://www.theborneopost.com/2021/01/23/are-we-all-ready-tosucceed-in-our-online-learning/

Cheng, S. C., Chang, Y. C., Chiang, Y. L. F., Chien, Y. C., Cheng, M., Yang, C. H., Huang, C. H., \& Hsu, Y. N. (2020). First case of coronavirus disease 2019 (COVID-19) pneumonia in Taiwan. Journal of the Formosan Medical Association, 119(3), 747-751.

Ch'ng, B. (2020, April 15). Drive-through service in Klang for Covid-19 testing. The Star. Retrieved April 21, 2020, from https://www. thestar.com.my/metro/metro-news/2020/04/15/drive-throughservice-in-klang-for-covid-19-testing

Chong, S. C. (2020). Psychological impact of coronavirus outbreak on borderline personality disorder from the perspective of mentalizing model: A case report. Asian Journal of Psychiatry, 52, 102130.

Chua, S. (2020). Fatimah: 'Stay calm when undergoing compulsory quarantine'. The Borneo Post. Retrieved June 21, 2020, from https:// www.theborneopost.com/2020/05/08/fatimah-stay-calm-whenundergoing-compulsory-quarantine/

Chung, C. (2020). Huawei helps health ministry fight Covid-19 with tech solutions. The Star. Retrieved April 21, 2020, from https://www. thestar.com.my/news/nation/2020/04/10/huawei-helps-healthministry-fight-covid-19-with-tech-solutions

Dayak Daily. (2021a). More than 2,000 Covid-19 cases came from longhouses. Dayak Daily. Retrieved June 27, 2021, from https:// dayakdaily.com/more-than-2000-covid-19-cases-came-fromlonghouses/

Dayak Daily. (2021b). Only one new Covid-19 case reported at Sibu Jaya flats. Dayak Daily. Retrieved June 27, 2021, from https:// dayakdaily.com/only-one-new-covid-19-case-reported-at-sibujaya-flats/

Department of Statistics Malaysia. (2020a). Current population estimates, Malaysia, 2020. Retrieved June 19, 2020, from https://www.dosm. gov.my/v1/index.php?r=column/cthemeByCat\&cat=155\&bul_id= OVByWjg5YkQ3MWFZRTN5bDJiaEVhZz09\&menu_id= L0pheU43NWJwRWVSZk1WdzQ4TlhUUT09\#: : text= Malaysia's\%20population\%20in\%202020\%20is,to\%203.0\% 20million\%20(2020).

Department of Statistics Malaysia. (2020b). Report of special survey on effects of COVID-19 on economy \& individual - Round 1. Retrieved June 19, 2020, from https://www.dosm.gov.my/v1/

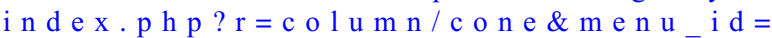
d3pnMXZ4ZHJjUnpnYjNyUnJhek83dz09.

Department of Statistics Singapore. (2020). Singapore Population. Retrieved June 19, 2020, from https://www.singstat.gov.sg/ modules/infographics/population

Etkind, S. N., Bone, A. E., Lovell, N., Cripps, R. L., Harding, R., Higginson, I. J., \& Sleeman, K. E. (2020). The role and response of palliative care and hospice Services in Epidemics and Pandemics: A rapid review to inform practice during the COVID-19 pandemic. Journal of Pain and Symptom Management, 60(1), e31-e40.

Fevre, J. L. (2020). COVID-19 in Asean: Update for April 29 - Active cases continue to fall in Malaysia \& Thailand. Asean news today. Retrieved June 15, 2021, from https://aecnewstoday.com/2020/ covid-19-in-asean-update-for-april-29/

Geddies, J., \& Aravindan, A. (2020). Why is Singapore's COVID-19 death rate the world's lowest. Reuters. Retrieved January 21, 2021, from https://www.reuters.com/article/health-coronavirus-singaporeexplainer-idUSKBN2680TF

Geraldine, A. (2020). Let the Covid-19 case spike from last Sabah election be a lesson to all. New Strait Times. Retrieved January 22, 2021, from https:/www.nst.com.my/news/nation/2020/11/640350/letcovid-19-case-spike-last-sabah-election-be-lesson-all

Gill, B. S., Jayaraj, V. J., Singh, S., Mohd Ghazali, S., Cheong, Y. L., Md Iderus, N. H., Sundram, B. M., Aris, T. B., Mohd Ibrahim, H., Hong, B. H., \& Labadin, J. (2020). Modelling the effectiveness of epidemic control measures in preventing the transmission of COVID-19 in Malaysia. International Journal of Environmental Research and Public Health, 17(15), 5509.

Government of Singapore. (2020). How voting will be safely conducted if done during COVID-19 situation. Retrieved January 18, 2021, 
from https://www.gov.sg/article/how-voting-will-be-safelyconducted-if-done-during-covid-19-situation

Grubic, N., Badovinac, S., \& Johri, A. M. (2020). Student mental health in the midst of the COVID-19 pandemic: A call for further research and immediate solutions. International Journal of Social Psychiatry, 66(5), 517-518.

Gunnell, D., Appleby, L., Arensman, E., Hawton, K., John, A., Kapur, N., Khan, M., O'Connor, R. C., Pirkis, J., Caine, E. D., \& Chan, L. F. (2020). Suicide risk and prevention during the COVID-19 pandemic. The Lancet Psychiatry, 7(6), 468-471.

Hassan, H. (2020). Malaysia frets over foreign worker housing as Covid19 infections surge. The Straits Times. Retrieved June 15, 2021, from https://www.straitstimes.com/asia/se-asia/malaysia-frets-overforeign-worker-housing-as-covid-19-infections-surge

Hassan, M.R., Subahir, M.N., Rosli, L., Din, S.N.A.C.M., Ismail, N.Z., Bahuri, N.H.A., Ibrahim, F., Othman, N., Abas, Z. \& Nawi, A.M. (2021). Malaysian enhanced movement control order (EMCO): A unique and impactful approach to combating pandemic COVID-19. Journal of Health Research, Ahead-of-Print (ahead-of-print).

Hassandarvish, M. (2020). Malaysian expert: Silent mental illness 'pandemic' to arrive following COVID-19 economic fallout. Malay Mail. Retrieved June 02, 2020, from https://malaymail.com/news/ life/2020/04/28/malaysian-expert-silent-mental-illness-pandemicto-arrive-following-covid-1/1860920

Henrich, J., Heine, S. J., \& Norenzayan, A. (2010). The weirdest people in the world? The Behavioral and Brain Science, 33(2-3), 61-83.

Holmes, E. A., O'Connor, R. C., Perry, V. H., Tracey, I., Wessely, S., Arseneault, L., Ballard, C., Christensen, H., Silver, R. C., Everall, I., \& Ford, T. (2020). Multidisciplinary research priorities for the COVID-19 pandemic: A call for action for mental health science. The Lancet Psychiatry, 7(6), 547-560.

Holt-Lunstad, J., Smith, T. B., Baker, M., Harris, T., \& Stephenson, D. (2015). Loneliness and social isolation as risk factors for mortality: A meta-analytic review. Perspectives on Psychological Science, 10(2), 227-237.

Hwang, T.-J., Rabheru, K., Peisah, C., Reichman, W., \& Ikeda, M. (2020). Loneliness and social isolation during the COVID-19 pandemic. International Psychogeriatrics, 32(10), 1217-1220.

Jaipragas, B. (2020). Coronavirus Malaysia: More heat on Muhyiddin after minister escapes punishment for breaking quarantine rules. South China Morning Post. Retrieved June 21, 2020, from https:// www.scmp.com/week-asia/politics/article/3106515/coronavirusmalaysia-more-heat-muhyiddin-after-minister-escapes

Jian, S. W., Cheng, H. Y., Huang, X. T., \& Liu, D. P. (2020). Contact tracing with digital assistance in Taiwan's COVID-19 outbreak response. International Journal of Infectious Diseases, 101, 348-352.

Kanyakumari, D. (2020). COVID-19 cases in Malaysia crosses 3,000 mark. CNA. Retrieved June 01, 2020, from https://www. channelnewsasia.com/news/asia/malaysia-coronavirus-covid-19cases-3000-mark-12602612

Kaos, J. (2020). Covid-19 update: 94 new cases reported, no new death. The Star. Retrieved June 01, 2020, from https://www.thestar.com. my/news/nation/2020/04/29/covid-19-update-94-new-casesreported-no-new-deaths

Kaos, J., \& Chung, C. (2020). 31 new cases detected, lowest since march 12. The Star. Retrieved June 01, 2020, from https://www.thestar. com.my/news/nation/2020/04/29/31-new-cases-detected-lowestsince-march-12

Kaur, S. (2020). The coronavirus pandemic in Malaysia: A commentary. Psychological Trauma Theory Research Practice and Policy, 12(5), 482-484.

Kaur, K., Kunasegaran, M., Singh, J., Salome, S., \& Sandhu, S. K. (2020). Impact of the first phase of movement control order during the COVID-19 pandemic in Malaysia on purchasing behavior of Malaysian consumers. Journal of Humanities and Social Sciences Research, 2, 131-144.
Khalid, N. (2020). Impact of pandemic on economy and recovery policy. Bernama. Retrieved June 03, 2020, from https://www.bernama. com/en/features/news.php?id=1829686

Khor, V., Arunasalam, A., Azli, S., Khairul-Asri, M. G., \& Fahmy, O. (2020). Experience from Malaysia during the COVID-19 movement control order. Urology, 141, 179-180.

Kim, D., Pan, Y., \& Park, H. S. (1998). High-versus low-context culture: A comparison of Chinese, Korean, and American cultures. Psychology and Marketing, 15(6), 507-521.

KPMG. (2020a). Singapore government and institution measures in response to COVID-19. Retrieved June 12, 2021, from https://home. $\mathrm{kpmg} / \mathrm{xx} / \mathrm{en} / \mathrm{home} /$ insights/2020/04/singapore-government-andinstitution-measures-in-response-to-covid.html

KPMG. (2020b). Taiwan government and institution measures in response to COVID-19. Retrieved June 12, 2021, from https://home. $\mathrm{kpmg} / \mathrm{xx} / \mathrm{en} / \mathrm{home} /$ insights/2020/04/taiwan-government-andinstitution-measures-in-response-to-covid.html

Kuo, C.-C. (2021). COVID-19 in Taiwan: Economic impacts and lessons learned. Asian Economic Papers, 20(2), 98-117.

Lee, S. J., \& Kim, Y. (2018). Economy doesn't buy community wellbeing: A study of factors shaping community wellbeing in South Korea. International Journal of Community Well-Being, 1(1), 33-44

Lei, M. K., \& Klopack, E. T. (2020). Social and psychological consequences of the Covid-19 outbreak: The experiences of Taiwan and Hong Kong. Psychological Trauma Theory Research Practice and Policy, 12(S1), S35-S37.

Lim, L. L. (2020a). The socioeconomic impacts of COVID-19 in Malaysia: Policy review and guidance for protecting the most vulnerable and supporting enterprises. Retrieved June 12, 2021, from https://www.ilo.org/asia/publications/WCMS 751600/lang-en/ index.htm

Lim, M. Z. (2020b). Nearly half of migrant workers in dormitories have had Covid-19. The Straits Times. Retrieved June 12, 2021, from https://www.straitstimes.com/singapore/nearly-half-of-migrantworkers-in-dormitories-have-had-covid-19

Malaysia Communications and Multimedia Commission. (2020, April 22). COVID-19: MySejahtera app helps users monitor personal health status. Retrieved June 18, 2020, from https://www.mcmc. gov.my/en/media/press-clippings/covid-19-mysejahtera-app-helpsusers-monitor-perso

Mat, N. F. C., Edinur, H. A., Razab, M. K. A. A., \& Safuan, S. (2020). A single mass gathering resulted in massive transmission of COVID19 infections in Malaysia with further international spread. Journal of Travel Medicine, 27(3).

Ministry of Health Malaysia. (2020). Covid-19: Social distancing guidelines for workplace, homes and individuals. Retrieved July 06, 2021 from http://covid-19.moh.gov.my/garis-panduan/garis-panduankkm/Annex_26_COVID_guide_for_Social_Distancing_24032020. pdf

Ministry of Health Singapore. (2021). Case summary in Singapore (as at 29 Jan 2021, 1200h). Retrieved January 18, 2021, from https:// www.moh.gov.sg/covid-19

Mohtar, J. (2020). Stimulus injection working, as re-opening gathers pace. New Straits Times. Retrieved January 18, 2021, from https:// www.nst.com.my/opinion/columnists/2020/07/610088/stimulusinjection-working-re-opening-gathers-pace

Murad, D. (2020). Polls in the time of Covid-19. The Star. Retrieved January 18, 2021, from https://www.thestar.com.my/news/focus/ 2020/10/11/polls-in-the-time-of-covid-19

Murugappan, R. (2020). How COVID-19 isolation affects our mental health. The Star. Retrieved June 18, 2020, from https://www. thestar.com.my/lifestyle/health/2020/04/08/how-isolation-forcovid-19-affects-our-mental-health

Murugiah, S. (2020). Malaysia unemployment rate is likely to hover between $6 \%$ and $8 \%$ in 2020 - AmBank Research. The Edge 
Markets. Retrieved June 18, 2020, from https://www. theedgemarkets.com/article/malaysia-unemployment-rate-likelyhover-between-6-and-8-2020-ambank-research

Ngui, Y., \& Chew, E. (2020). Genting Malaysia is said to cut $15 \%$ of its workforce. The Edge Markets. Retrieved June 18, 2020, from https://www.theedgemarkets.com/article/genting-malaysia-mulling3000-job-cuts-\%E2\%80\%94-report

Nienhaus, A., \& Hod, R. (2020). COVID-19 among health workers in Germany and Malaysia. International Journal of Environmental Research and Public Health, 17(13), 4881.

Our World in Data. (2021). Case fatality rate vs. total confirmed COVID19 deaths, Apr 30, 2021. Retrieved June 27, 2021, from https:// ourworldindata.org/grapher/deaths-covid-19-vs-case-fatality-rate? time $=2021-04-30 \&$ country $=$ TWN $\sim$ SGP $\sim$ MYS

Palansamy, Y. (2020). Minister: RM1,000 compound rule for MCO defiers enforced yesterday, 95 summons issued. Malay Mail. Retrieved January 22, 2021, from https://www.malaymail.com/ news/malaysia/2020/04/09/minister-cops-issued-95-compoundfines-to-mco-violators-yesterday/1855062

Perlman, H. (2019). France ups minimum wages for 2020, social contributions affected. Retrieved June 24, 2021, from https://news. bloombergtax.com/payroll/france-ups-minimum-wages-for-2020social-contributions-affected

Povera, A., \& Yunus, A. (2020). Education ministry to organise homebased learning during MCO [NSTTV]. The Star. Retrieved June 21, 2020, from https://www.nst.com.my/news/nation/2020/04/583180/ education-ministry-organise-home-based-learning-during-mconsttv

Prime Minister's Office of Malaysia. (2020). The Prime Minister's special message on COVID-19 - 16 March 2020. Retrieved June 29, 2020, from https://www.pmo.gov.my/2020/03/perutusan-khas-yabperdana-menteri-mengenai-covid-19-16-mac-2020/

Profdten, D., \& Ahmad, R. (2021). COVID-19: Current situation in Malaysia (updated daily). The Star. Retrieved February 01, 2021, from https://www.thestar.com.my/news/nation/2020/03/23/covid19-current-situation-in-malaysia-updated-daily

Qiu, J., Shen, B., Zhao, M., Wang, Z., Xie, B., \& Xu, Y. (2020). A nationwide survey of psychological distress among Chinese people in the COVID-19 epidemic: Implications and policy recommendations. General Psychiatry, 33(2), e100213.

Rahim, R. (2020). Travel limited to $10 \mathrm{~km}$ to buy necessities. The Star. Retrieved June 01, 2020, from https://www.thestar.com.my/news/ nation/2020/04/02/travel-limited-to-10km-to-buy-necessities

Salim, S. (2020). Covid-19: Three new clusters emerge while four end. The Edge Markets. Retrieved June 21, 2020, from https://www. theedgemarkets.com/article/covid19-three-new-clusters-emergewhile-four-end

Sarawak Disaster Management Committee. (2021). Sarawak Disaster Management Commitee. Retrieved June 25, 2021, from https:// sarawakdisastermc.com/

Sarkodie, S. A., \& Owusu, P. A. (2021). Global assessment of environment, health and economic impact of the novel coronavirus (COVID-19). Environment, Development and Sustainability, 23(4), 5005-5015.

Shah, A. U. M., Safri, S. N. A., Thevadas, R., Noordin, N. K., Abd Rahman, A., Sekawi, Z., Ideris, A., \& Sultan, M. T. H. (2020). COVID-19 outbreak in Malaysia: Actions taken by the Malaysian government. International Journal of Infectious Diseases, 97, 108116.

Shankar, A. C. (2021). Govt warns it will impose full-scale lockdown if infections don't decrease - Eurocham. The Edge Markets. Retrieved February 06, 2021, from https://www.theedgemarkets. com/article/government-launch-fullscale-lockdown-after-feb-4-ifinfection-rates-do-not-decline-eurocham
Shanmugam, H., Juhari, J. A., Nair, P., Ken, C. S., \& Guan, N. C. (2020). Impacts of COVID-19 pandemic on mental health in Malaysia: A single thread of hope. Malaysian Journal of Psychiatry, 29(1).

Song, Q. Y., \& Ling, M. J. N. (2020). COVID-19 pandemic: An unseen's evolution war. Journal of Lumbini Medical College, 8(1).

Sukumaran, T. (2020). Coronavirus Malaysia: PM blames Sabah election as among causes of huge infection surge. South China Morning Post. Retrieved February 06, 2021, from https://www.scmp.com/ week-asia/politics/article/3104903/amid-coronavirus-surgemalaysia-asks-what-went-wrong-muhyiddin

Sundarasen, S., Chinna, K., Kamaludin, K., Nurunnabi, M., Baloch, G. M., Khoshaim, H. B., Hossain, S. F. A., \& Sukayt, A. (2020). Psychological impact of covid-19 and lockdown among university students in Malaysia: Implications and policy recommendations. International Journal of Environmental Research and Public Health, 17(17), 6206.

Surendran, S. (2021). Surviving the impact of Covid-19: A trying year for job holders. The Edge Markets. Retrieved June 15, 2020, from https://www.theedgemarkets.com/article/surviving-impactcovid19-trying-year-job-holders

Taiwan Centers for Diesease Control. (2021). Taiwan Centers for Diesease Control. Retrieved February 06, 2021, from https://www. cdc.gov.tw/En

Tan, V. (2020). COVID-19: Malaysia extends movement control order for third time until May 12. CNA. Retrieved June 24, 2020, from $\mathrm{https}$ ://www.channelnewsasia.com/news/asia/covid-19-malaysiaextends-movement-control-order-may-12-12670228

Tan, A. (2021a). 58 new Covid-19 cases in Singapore, including 3 in the community. The Straits Times. Retrieved February 06, 2021, from https:/www.straitstimes.com/singapore/health/58-new-covid-19cases-in-singapore-three-of-them-in-the-community.

Tan, N. (2021b). Our frontliners need help! The Star. Retrieved February 06, 2021, from https://www.thestar.com.my/opinion/columnists/allthe-pieces-matter/2021/01/24/our-frontliners-need-help

Tanzizi, N. H. (2020). Two fined RM1,000 for defying MCO [NSTTV]. New Straits Times. Retrieved June 06, 2020, from https://www.nst. com.my/news/crime-courts/2020/03/577987/two-fined-rm1000defying-mco-nsttv

Tay, K., Kamarul, T., Lok, W., Mansor, M., Li, X., Wong, J., \& Saw, A. (2020). COVID-19 in Singapore and Malaysia: Rising to the challenges of orthopaedic practice in an evolving pandemic. Malaysian Orthopaedic Journal, 14(2).

Teoh, M. (2020). Malaysians show their kind side during the Covid-19 pandemic and MCO. The Star. Retrieved June 09, 2020, from https:/www.thestar.com.my/lifestyle/people/2020/04/16/ malaysians-show-their-kind-side-during-the-covid-19-pandemicand-mco

The Star. (2020). Malaysia: Economy in 2020 - the year that wasn't. The Star. Retrieved June 06, 2021, from https://www.thestar.com.my/ aseanplus/aseanplus-news/2020/11/29/malaysia-economy-in2020\%2D\%2D-the-year-that-wasn039t

The Star. (2021). Health minister: 552,862 individuals have completed both doses of Covid vaccine in Malaysia. The Star. Retrieved June 25, 2021, from https://www.thestar.com.my/news/nation/ 2021/05/01/552862-people-have-completed-both-doses-of-covid19-vaccine-says-health-minister

The Straits Times. (2021). Malaysia Covid-19 cases show signs of escalating with spikes in Kedah and Sabah. The Straits Times. Retrieved February 10, 2021, from https://www.straitstimes.com/asia/se-asia/ malaysia-covid-19-cases-show-signs-of-escalating-with-spikes-inkedah-and-sabah

Thiessen, T. (2020). French lockdown to last weeks, as coronavirus death toll spirals. Forbes. Retrieved June 10, 2021, from https://www. forbes.com/sites/tamarathiessen/2020/03/28/french-coronaviruslockdown-to-last-weeks/ 
Thoits, P. A., \& Hewitt, L. N. (2001). Volunteer work and well-being. Journal of Health and Social Behavior, 42, 115-131.

Tierney, S., \& Mahtani, K. R. (2020). Volunteering during the COVID19 pandemic: What are the potential benefits to people's well-being? Retrieved July 20, 2020, from https://www.cebm.net/covid-19/ volunteering-during-the-covid-19-pandemic-what-are-thepotential-benefits-to-peoples-well-being/

Timbuong, J. (2020). Military ready to assist cops, says armed forces chief. The Star. Retrieved June 20, 2020, from https://www. thestar.com.my/news/nation/2020/03/20/military-ready-to-assistcops-says-armed-forces-chief

Trading Economics. (2021). Unemployment Rate. Retrieved June 26, 2021, from https://tradingeconomics.com/country-list/ unemployment-rate

Trautwein, S., Liberatore, F., Lindenmeier, J., \& Von Schnurbein, G. (2020). Satisfaction with informal volunteering during the Covid19 crisis: An empirical study considering a swiss online volunteering platform. Journal of Voluntary Action Research, 49(6), 1142-1151.

Ungku, F. (2020). Covid-19: Singapore launches contact tracing mobile app to track coronavirus infections. The Star. Retrieved January 26, 2021, from https://www.thestar.com.my/tech/tech-news/2020/03/ 20/covid-19-singapore-launches-contact-tracing-mobile-app-totrack-coronavirus-infections

Vanar, M. (2020). Five 'recovered' COVID-19 cases in Sabah found positive in follow-up tests. The Star. Retrieved June 03, 2020, from https:// www.thestar.com.my/news/nation/2020/04/21/five-recovered-covid19-cases-in-sabah-found-positive-in-follow-up-tests

Veerasamy, C., Sambasivan, M., \& Kumar, N. (2013). Individual skills based volunteerism and life satisfaction among healthcare volunteers in Malaysia: Role of employer encouragement, self-esteem and job performance, a cross-sectional study. PLoS One, 8(10), e77698.

Wang, C., \& Ellis, S. (2020). How Taiwan's COVID response became the world's envy. Fortune. Retrieved January 20, 2021, from https:// fortune.com/2020/10/31/taiwan-best-covid-response/

Wang, X., Shi, L., Zhang, Y., Chen, H., \& Sun, G. (2021). Policy disparities in fighting COVID-19 among Japan, Italy, Singapore and China. International Journal for Equity in Health, 20(1).
Wilson, J. (2012). Volunteerism research: A review essay. Nonprofit and Voluntary Sector Quarterly, 41(2), 176-212.

Woon, L. S.-C., Sidi, H., Nik Jaafar, N. R., \& Leong Bin Abdullah, M. F. I. (2020). Mental health status of university healthcare workers during the COVID-19 pandemic: A post-movement lockdown assessment. International Journal of Environmental Research and Public Health, 17(24), 9155.

World Health Organization. (2020). World Health Organization assesses the world's health systems. Retrieved January 20, 2021, from https:// www.who.int/news/item/07-02-2000-world-health-organizationassesses-the-world's-health-systems

Worldometers. (2021a). Total coronavirus cases in France. Retrieved June 25, 2021, from https://www.worldometers.info/coronavirus/ country/france/

Worldometers. (2021b). Total coronavirus cases in Malaysia. Retrieved June 25, 2021, from https://www.worldometers.info/coronavirus/ country/malaysia/

Yang, C. J., Chen, T. C., \& Chen, Y. H. (2020). The preventive strategies of community hospital in the battle of fighting pandemic COVID-19 in Taiwan. Journal of Microbiology, Immunology and Infection, 53(3), 381-383.

Yong, M. (2020). Timeline: How the COVID-19 outbreak has evolved in Singapore so far. Channel News Asia. Retrieved January 15, 2021, from https://www.channelnewsasia.com/news/singapore/singaporecovid-19-outbreak-evolved-coronavirus-deaths-timeline-12639444

Zainul, E. (2020). Over 2,300 volunteers join COVID-19 frontline but MoH seeks more. The Edge Markets. Retrieved June 15, 2020, from https://www.theedgemarkets.com/article/over-2300-volunteersjoin-covid19-frontline-moh-seeks-more

Zolkepli, F. (2020). Covid-19 PUI found dead in Serdang hospital toilet, suicide suspected (updated). The Star. Retrieved June 15, 2020, from https://www.thestar.com.my/news/nation/2020/03/28/covid19-pui-found-dead-in-serdang-hospital-toilet-suicide-suspected

Publisher's Note Springer Nature remains neutral with regard to jurisdictional claims in published maps and institutional affiliations. 